\title{
EFFISIENSI TEKNIS USAHATANI KEDELAI PADA LAHAN SAWAH DAN DARAT DI KECAMATAN JATIWARAS
}

\section{TECHNICAL EFFICIENCY OF SOYBEAN FARMING IN PADDY FIELD AND DRY LAND IN JATIWARAS DISTRICT}

\author{
Rian Kurnia*, Ivan Sayid Nurahman \\ *Fakultas Pertanian Universitas Galuh Ciamis \\ "Email: rian.agribusiness@gmail.com \\ (Diterima 13-11-2020; Disetujui 29-12-2020)
}

\begin{abstract}
ABSTRAK
Pemenuhan kebutuhan kedelai sebanyak 67,99 persen harus diimpor dari luar negeri, untuk mengatasi defisit produksi kedelai pemerintah Indonesia telah mengupayakan berbagai program pengembangan kedelai. Penelitian dilaksanakan dengan tujuan untuk: (1) Menganalisis pengaruh penggunaan faktor-faktor produksi pada usahatani kedelai di Kecamatan Jatiwaras Kabupaten Tasikmalaya, (2) Menganalisis efisiensi teknis usahatani kedelai di lahan sawah dan lahan darat di Kecamatan Jatiwaras Kabupaten Tasikmalaya. Metode penelitian yang digunakan dalam penelitian ini adalah metode survei eksplanatori dengan mengambil kasus pada usahatani kedelai di Kecamatan Jatiwaras, Kabupaten Tasikmalaya. Sampel diambil menggunakan Multistage Cluster Random Sampling, maka diperoleh sampel sebanyak 127 orang dari populasi petani kedelai sebanyak 185 orang dari dua desa yang dipilih secara acak (Desa Jatiwaras dan Papayan), dari 11 desa sentra kedelai yang menanam di agroekosistem sawah dan darat (Kaputihan, Neglasari, Sukakerta, Setiawangi, Papayan, Jatiwaras, Ciwarak, Kersagalih, Kertarahayu, Mandalamekar, Mandalahurip). Analisis yang digunakan untuk efisiensi teknis dan menentukan faktor-faktor produksi yang secara langsung mempengaruhi output produksi yang dihasilkan adalah fungsi produksi stochastic frontier Cobb-Douglas. Hasil penelitian menunjukkan terdapat satu variabel yang berpengaruh secara signifikan di lahan darat terhadap tingkat produksi kedelai yakni pupuk, sedangkan variabel luas lahan, benih, pestisida dan tenaga kerja sedangkan petani di lahan sawah terdapat dua variabel yang berpengaruh secara signifikan terhadap tingkat produksi kedelai yakni luas lahan dan tenaga kerja, benih, pupuk, dan pestisida tidak signifikan. Petani kedelai baik di lahan darat maupun lahan sawah berada pada tahap III (Tahap Irrasional). Rata-rata nilai Efisiensi Teknis (TE) Efisiensi Alokatif (AE) dan Efisiensi Ekonomis (EE) di lahan sawah adalah 99,97 TE, 62,68 AE dan 62,68 EE sedangkan Rata-rata nilai Efisiensi Teknis, Efisiensi Alokatif dan Efisiensi Ekonomis di lahan sawah adalah 21,35 TE, 19,42 AE dan 19,42 EE. Nilai tersebut menunjukn usahatani kedelai di lahan darat lebih efisien baik dilihat dari nila TE, AE maupun EE
\end{abstract}

Kata kunci: efisiensi teknis, faktor produksi, kedelai

\section{ABSTRACT}

Fulfilling the needs of 67.99 percent of soybeans must be imported from abroad. To overcome the deficit in soybean production, the Indonesian government has pursued various soybean development programs. The research was carried out with the aim of: (1) Analyzing the effect of using production factors both simultaneously and partially on soybean farming in Jatiwaras District, Tasikmalaya Regency, (2) Analyzing the technical efficiency of soybean farming in paddy fields and land land in Jatiwaras District, Tasikmalaya Regency. The research method used in this study is an explanatory survey method by taking cases on soybean farming in Jatiwaras District, Tasikmalaya Regency. Samples were taken using Multistage Cluster Random Sampling, then a sample of 127 people was obtained from a population of 185 soybean farmers from two randomly selected villages (Jatiwaras and Papayan Villages), from 11 soybean center villages that planted in rice fields and land agro-ecosystems (Kaputihan, Neglasari)., Sukakerta, Setiawangi, Papayan, 
Jatiwaras, Ciwarak, Kersagalih, Kertarahayu, Mandalamekar, Mandalahurip). The analysis used for technical efficiency and determining the production factors that directly affect the resulting production output is the Cobb-Douglas stochastic frontier production function. The results of this study indicate that there is one variable that significantly influences the level of soybean production, namely fertilizer, Meanwhile, the variables of land area, seeds, pesticides and labor, meanwhile there are two variables that significantly influence the level of soybean production, namely land area and labor, seeds, fertilizers, and insignificant pesticides. Soybean farmers both on land and rice fields are in stage III (Irrational Stage). The average value of Technical Efficiency (TE) Allocative Efficiency (AE) and Economic Efficiency (EE) in paddy fields is 99.97 TE, 62.68 $A E$ and $62.68 E E$ while the average values of Technical Efficiency, Allocative Efficiency and Efficiency The economists in rice fields are 21.35 TE, $19.42 \mathrm{AE}$ and $19.42 \mathrm{EE}$. This value shows that soybean farming on land is more efficient in terms of TE, AE and EE tilapia

Key words: technical efficiency, production factors, soybeans

\section{PENDAHULUAN}

Pembangunan pertanian merupakan bagian dari pembangunan ekonomi dan masyarakat secara umum. Pembangunan pertanian memberikan sumbangan kepada masyarakat serta menjamin bahwa pembangunan yang menyeluruh itu mencakup penduduk yang hidup dari bertani, tantangan pembangunan pertanian seperti jumlah penduduk yang menyentuh angka 258 juta jiwa dengan laju pertumbuhan 1,36 persen (BPS, 2017), konversi lahan pertanian 96.500 ha/tahun dan belum terkendali sepenuhnya (Mulyani, 2014), masih rendahnya akses terhadap sumber pembiayaan, teknologi, informasi pasar, dan dampak negatif perubahan iklim global (Irsal dkk. 2018), arus urbanisasi dan peningkatan kesejahteraan yang mendorong perubahan pola konsumsi pangan, baik kuantitas, kualitas dan keberagaman pangan yang mendorong peningkatan ketergantungan terhadap pangan impor (food trap).

Kedelai memiliki beragam manfaat diantaranya sebagai bahan baku agroindustri tahu, tempe, oncom, tauco, susu kedelai, dan lain-lain. Bagian kedelai yang biasanya dimanfaatkan adalah bijinya yang merupakan salah satu sumber protein nabati, kandungan protein kedelai sekitar 35 persen, bahkan pada verietas unggul kadar proteinnya dapat mencapai 40 sampai dengan 43 persen. Kedelai juga mengandung zat anti oksidan yang tinggi, vitamin (asam fitat), lesitin, dan zat lainnya yang sangat bermanfaat bagi kesehatan (Koswara, 2009).

Menurut Pusat Data dan Sistem Informasi Pertanian Kementerian Pertanian (2017), Masalah lain yang harus diperhatikan adalah produktivitas 
kedelai di tingkat petani yang masih rendah, rata-rata 1,3 ton per hektar dengan kisaran produksi di tingkat petani antara 0,6-2,0 ton/ha, sedangkan secara teknis potensi hasilnya dapat mencapai 3,0 ton per hektar. Belum tercapainya produktivitas tersebut sebagai akibat panggunaan sarana produksi yang belum sesuai dengan anjuran. Kesenjangan produktivitas yang sangat besar tersebut memberikan peluang peningkatan produksi melalui peningkatan produktivitas di tingkat petani.

Dalam berusahatani terdapat banyak faktor yang mempengaruhi keputusan petani dalam mengusahakan komoditi pada lahan yang dimilikinya, begitu juga petani di Kecamatan Jatiwaras, keterbatasan modal, tingginya biaya produksi, menyebabkan petani sulit untuk dapat mengkombinasikan faktor produksi yang efisien agar diperoleh keuntungan maksimum. Menurut Isyanto et al (2021), kemampuan petani dalam mengalokasikan sumberdaya akan berpengaruh terhadap produksi dan tingkat efisiensi yang dicapai.

Berdasarkan uraian maka tujuan dari penelitian ini adalah:

Menganalisis pengaruh penggunaan faktor-faktor produksi, baik secara simultan dan parsial, pada usahatani kedelai di Kecamatan Jatiwaras

Kabupaten Tasikmalaya, dan

Menganalisis efisiensi teknis usahatani kedelai di lahan sawah dan lahan darat di Kecamatan Jatiwaras Kabupaten Tasikmalaya.

\section{METODE PENELITIAN}

Metode penelitian yang digunakan dalam penelitian ini adalah metode survei eksplanatori dengan mengambil kasus pada usahatani kedelai di Kecamatan Jatiwaras, Kabupaten Tasikmalaya. Sampel diambil menggunakan Multistage Cluster Random Sampling, maka diperoleh sampel sebanyak 127 orang dari populasi petani kedelai sebanyak 185 orang dari dua desa terpilih secara random (Desa Jatiwaras dan Papayan), dari 11 desa sentra kedelai yang menanam di lahan sawah dan darat (Kaputihan, Neglasari, Sukakerta, Setiawangi, Papayan, Jatiwaras, Ciwarak, Kersagalih, Kertarahayu, Mandalamekar, Mandalahurip). Analisis yang digunakan untuk menentukan faktor-faktor produksi yang secara langsung mempengaruhi output produksi yang dihasilkan adalah fungsi produksi stochastic frontier CobbDouglas. Produksi kedelai di Kecamatan Jatiwaras di lahan sawah dan darat dianalisis secara terpisah dengan 
menggunakan model fungsi produksi stochastic frontier Cobb-Douglas berikut:

$$
\ln Y_{i}=\beta_{0}+\sum_{j=1}^{5} \beta_{j} \ln X_{j_{i}}+v_{i}-u_{i}
$$

dimana:

$Y_{i}=$ Output produksi kedelai dari petani ke- $i(\mathrm{~kg})$

$X_{1 i}=$ Luas lahan kedelai petani ke- $i$ (meter)

$X_{2 i}=$ Banyaknya benih yang digunakan petani ke-i $(\mathrm{kg})$

$X_{3 i}=$ Banyaknya pupuk yang digunakan petani ke- $i(\mathrm{~kg})$

$X_{4 i}=$ Banyaknya pestisida yang digunakan petani ke- $i$ (liter)

$X_{5_{i}}=$ Banyaknya tenaga kerja yang digunakan petani ke- $i$ (HOK)

$\beta_{0}=$ Konstanta (vektor parameter)

$\beta_{j}=$ Vektor parameter fungsi produksi

$(j=1,2, \ldots, 5)$

$v_{i}=$ Random error term

\section{$u_{i}=$ Nonnegative error term}

\section{HASIL DAN PEMBAHASAN}

Model yang digunakan untuk mengestimasi fungsi produksi kedelai di daerah penelitian yaitu model fungsi produksi frontier stochastic CobbDouglas. Parameter yang digunakan pada model ini diestimasi dengan metode Maximum Likelihood Estimated (MLE) yang menggambarkan hubungan antara produksi (output) maksimum yang dapat dicapai pada tingkat penggunaan faktorfaktor produksi (input) yang ada. Nilai MLE diperoleh dengan menggunakan program STATA sebagaimana tersaji pada Tabel 1.

Tabel 1. Hasil Estimasi Parameter Stochastik Frontier Analysis (SFA)

\begin{tabular}{lrrrrrr}
\hline \multirow{2}{*}{ Faktor } & \multicolumn{3}{c}{ Lahan darat } & \multicolumn{3}{c}{ Lahan Sawah } \\
\cline { 2 - 7 } & \multicolumn{1}{c}{ Coef. } & Std. Error & $\mathrm{P}>$ lzl & \multicolumn{1}{c}{ Coef. } & Std. Error & P > lzl \\
\hline Konstanta & $-0,781$ & 0,027 & 0,000 & $-0,169$ & 0,025 & 0,000 \\
Luas Lahan & 0,001 & 0,002 & 0,529 & $-2,500$ & 0,019 & $0,000^{*}$ \\
Benih & 0,030 & 0,019 & 0,111 & 0,005 & 0,004 & 0,226 \\
Pupuk & 0,546 & 0,089 & $0,000^{*}$ & $-0,001$ & 0,004 & 0,863 \\
Pestisida & 0,002 & 0,002 & 0,410 & 2,500 & 0,000 & 1,000 \\
Tenaga Kerja & $-1,026$ & 0,026 & 0,318 & 0,021 & 0,022 & $0,000^{*}$ \\
Uji F & 82,634 & & 0,000 & 175,807 & & 0,000 \\
R & 0,926 & & & 0,975 & & \\
$\mathrm{R}^{2}$ & 0,857 & & & 0,951 & & \\
\hline K & & & & & &
\end{tabular}

Keterangan: *signifikan pada 0,05 atau 5\%

\section{Analisis Fungsi Produksi Stochastic}

\section{Frontier di Lahan Darat}

Tabel 1 menunjukkan bahwa semua variabel faktor produksi secara simultan mampu memprediksi produksi yang dicapai petani secara signifikan.
Selanjutnya secara parsial, hasil analisis fungsi produksi stochastic frontier pada petani di lahan darat memperlihatkan bahwa dari kelima variabel independen, terdapat satu variabel yang berpengaruh secara signifikan terhadap tingkat 
produksi kedelai yakni pupuk, sedangkan 4 variabel lainnya tidak signifikan, yakni luas lahan, benih, pestisida dan tenaga kerja.

Variabel pupuk memperlihatkan pengaruh positif dan signifikan, dengan koefisien regresi: 0,546, berarti bermakna bahwa setiap penambahan 1 satuan pupuk maka akan meningkatkan produksi kedelai sebesar $0,546 \mathrm{~kg}$. Dalam hal ini pupuk yang digunakan terdiri atas 4 jenis pupuk, yaitu: pupuk NPK, organik cair, petrobio dan rhizobium. Di lahan darat pupuk sangat berpengaruh terhadap produksi karena penggunaan pupuk menentukan besarnya produksi yang diterima petani kedelai di lahan darat, penggunaan pupuk dengan kuantitas yang cukup, kualitas yang baik serta waktu pemberian yang sesuai di lokasi penelitian menyebabkan tanaman tumbuh sesuai harapan petani. Tanaman kedelai yang tumbuh subur akan menghasilkan produksi yang tinggi.

Luas lahan tidak berpengaruh secara signifikan disebabkan semakin luas lahan yang digarap maka perawatan tidak akan maksimal, hal ini terjadi karena tenaga kerja dalam usahatani di lahan darat sebagian besar dilakukan oleh tenaga kerja dalam keluarga, hanya dalam waktu-waktu tertentu saja petani melibatkan tenaga kerja di luar keluarga, seperti saat penanaman dan panen, maka faktor tenaga kerja juga tidak berpengaruh secara signifikan.

Pengendalian hama penyakit di lahan darat dilakukan jika sudah ada tanda serangan, hal inilah yang menyebabkan penggunaan faktor produksi pestisida tidak signifikan. Hama yang sudah terlanjur menyerang tanaman kedelai akan sulit untuk dikendalikan. Penggunaan dosis pestisida walaupun sudah mendekati anjuran, tetapi jika waktu pemberian tidak tepat maka tidak akan berpengaruh.

Benih yang digunakan di lahan darat memiliki kualitas yang kurang bagus, benih yang digunakan adalah benih bantuan dari pemerintah dalam program pengembangan kedelai. Benih merupakan faktor produksi yang sangat berpengaruh, penggunaan benih yang kurang baik akan menyebabkan produksi yang diterima juga tidak optimum, hal inilah yang menyebabkan penggunaan benih di lahan darat tidak berpengaruh secara signifikan, sedangkan penelitian Matakena (2012) dan Amaza dkk. (2008) menunjukan bahwa variabel lahan, tenaga kerja, dan pupuk berpengaruh nyata dan signifikan terhadap produksi kedelai. Sedangkan perbedaan dari kedua 


\section{EFFISIENSI TEKNIS USAHATANI KEDELAI PADA LAHAN SAWAH DAN DARAT \\ DI KECAMATAN JATIWARAS \\ Rian Kurnia, Ivan Sayid Nurahman}

penelitian tersebut, dimana pada penelitian Matakena (2012) menjelaskan bahwa variabel insektisida dan bibit tidak berpengaruh nyata dan signifikan terhadap produksi. Hal tersebut berbanding terbalik dengan hasil penelitian Amaza dkk. (2008), yang menjelaskan bahwa variabel bibit dan insektisida memiliki pengaruh yang signifkan terhadap produksi kedelai.

\section{Analisis Fungsi Produksi Stochastic}

\section{Frontier di Lahan Sawah}

Tabel 1 menunjukkan bahwa semua variabel faktor produksi secara simultan mampu memprediksi produksi yang dicapai petani secara signifikan. Selanjutnya secara parsial, hasil analisis fungsi produksi Stochastic Frontier pada petani di lahan sawah memperlihatkan bahwa dari kelima variabel independen, terdapat dua variabel yang berpengaruh secara signifikan terhadap tingkat produksi kedelai yakni luas lahan dan tenaga kerja, sedangkan benih, pupuk, dan pestisida tidak signifikan.

Luas lahan berpengaruh negatif dan signifikan terhadap tingkat produksi dengan koefisien regresi: $-2,250$, berarti bahwa setiap penambahan luas lahan justru akan menurunkan produksi kedelai sebesar 2,250 Kg. Hal ini bertentangan dengan penelitian Irawan (2014), Liu dkk. (2009), Ningsih dkk. (2014) serta Rahayu dan Riptanti (2010), yang menunjukan bahwa luas lahan berpengaruh positif terhadap produksi kedelai karena variabel yang berpengaruh besar terhadap peningkatan produksi kedelai adalah luas lahan. Peningkatan luas lahan belum tentu akan menghasilkan efisiensi teknis. Kemudian variabel kedua yang berpengaruh adalah tenaga kerja, variabel tenaga kerja memperlihatkan pengaruh positif, yakni dengan koefisien regresi: 0,021, hal ini berarti bahwa penggunaan tenaga kerja jika ditambah sebesar 1 satuan (HOK), akan menurunkan produksi kedelai 0,021 $\mathrm{Kg}$.

Faktor produksi luas lahan yang berpengaruh negatif terhadap produksi pada usahatani kedelai di lahan sawah disebabkan luasan lahan yang diusahakan petani cenderung sempit. Dengan sempitnya luas lahan maka penggunaan tenaga kerja akan optimum, karena dengan tenaga kerja yang digunakan minim tanaman kedelai akan terawat yang disebabkan sempitnya luas lahan, maka dari itu faktor produksi tenaga kerja di lahan sawah berpengaruh positif. Penggunaan benih di lahan sawah tidak berbeda jauh dari segi kualitas dengan 
penggunaan benih di lahan darat, kualitas benih yang kurang baik menyebabkan produksi yang diterima petani kurang optimum, hal inilah yang menyebabkan faktor produksi benih tidak berpengaruh secara signifikan.

Penggunaan pupuk pada usahatani kedelai di lahan sawah tidak diberikan dengan optimum, karena petani kedelai di lahan sawah berasumsi masih ada residu pupuk dari tanaman padi, hal ini yang menyebabkan penggunaan faktor produksi pupuk tidaj berpengaruh secara signifikan, sedangkan penggunaan pestisida pada usahatani kedelai di lahan sawah tidak jauh berbeda jika dibandingkan dengan penggunaan pestisida di lahan darat. dosis pestisida yang sudah sesuai anjuran tidak akan berarti jika pemberian tidak tepat waktu.

\section{Elastisitas Produksi di Lahan Sawah dan Darat}

Dari analisis fungsi produksi Stochastic Frontier, kita bisa melihat pada stage/daerah mana usahatani tersebut beroperasi. Seperti diungkapkan oleh Pyndick et al (2009), bahwa jumlah koefisien regresi pada fungsi produksi menunjukkan elastisitas produksi dan menunjukkan pada tahapan dimana usahatani dilakukan. Konsep elastisitas produksi menunjukan berapa kali produksi (output) meningkat jika ditambah satu satuan faktor produksi (input). Jika jumlah koefisien regresi/Elastisitas produksi (Ep) $\geq 1$, maka usahatani tersebut berada pada Tahap I (Tahap Irasional). Demikian jika jumlah regresi/Elastisitas produksi $(\mathrm{Ep}) \leq 0$, maka usahatani tersebut berada pada Tahap III (Tahap Irasional). Yang ideal usahatani yang memberikan keuntungan maksimum bagi pengusahanya ada di tahap II (Tahap Rasional) dimana elastisitas produksi berada $0<\mathrm{Ep}<1$.

Petani di lahan darat masih beroperasi pada Tahap III (Tahap Irasional) dengan jumlah koefisien Elastisitas produksi (Ep) $=-1,229$, sehingga belum bisa mencapai keuntungan maksimal. Pada petani di lahan sawah, diperoleh elastisitas produksi $($ Ep $)=-0,143$, jadi berada pada tahap III (Tahap Irasional). Tahap III dikatakan tahap irasional karena petani yang beroperasi pada tahap ini dikatakan tidak rasional.

Kondisi pada petani di lahan darat berbeda dengan petani di lahan sawah. Hal ini dikarenakan pada petani di lahan darat input yang paling dominan terhadap peningkatan produksi adalah pupuk dalam arti efisien usahatani yang 
dilakukannya, sedangkan pada petani di lahan sawah semakin luas lahan yang dikelola petani, maka semakin efisien usahatani yang dilakukannya. Kondisi lainnya yang mendukung keberadaan usahatani pada wilayah lahan sawah adalah tenaga kerja semakin baik, maka usahatani semakin efisien.

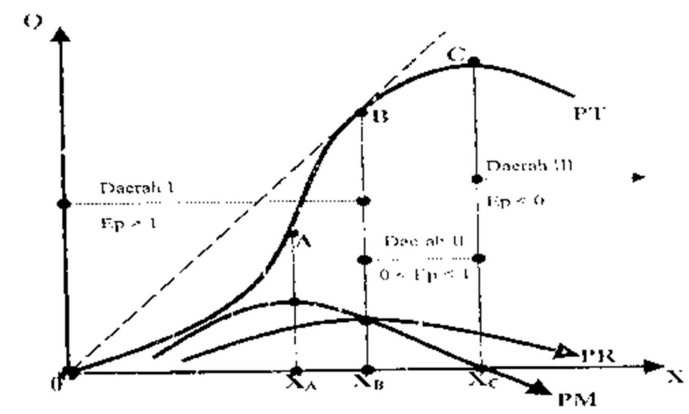

Gambar 1. Tiga Tahapan dalam Fungsi Produksi (Pyndick et al, 2009)

\section{Efisiensi Penggunaan Faktor Produksi}

Menurut Mubyarto (1987), istilah efisiensi sering dibahas dan dikenalkan dalam teori produksi. Pada dasarnya setiap usaha, begitupun usahatani kedelai, bertujuan untuk mencapai keuntungan maksimum. Untuk memperoleh keuntungan yang maksimum, maka perlu dipertimbangkan tidak hanya pertimbangan teknis saja, tetapi juga segi ekonomis. Dengan demikian, efisiensi merupakan tolok ukur untuk menilai keberhasilan proses produksi. Suatu kegiatan produksi akan memilih proses penggunaan input yang paling sedikit untuk menghasilkan output tertentu, yaitu suatu proses yang secara teknis paling efisien. Alternatif lainnya yaitu memilih proses produksi dengan biaya paling rendah untuk menghasilkan output tertentu, yaitu suatu proses produksi yang secara ekonomis paling efisien.

Efisiensi merupakan salah satu indikator dari keberhasilan usahatani yang dilakukan petani. Secara teoritis dikenal tiga istilah efisiensi, yaitu efisiensi teknis, efisiensi harga dan efisiensi alokatif. Efisiensi teknis dinyatakan dengan seberapa jauh penyimpangan suatu usahatani beroperasi dari fungsi produksi frontier pada tingkat teknologi tertentu. Menurut Coelli et al (1998), fungsi produksi frontier adalah fungsi produksi yang menggambarkan output maksimum yang dapat dicapai dari setiap tingkat penggunaan input. Apabila suatu usahatani berada pada titik di fungsi produksi frontier artinya usahatani tersebut efisiensi secara teknis. Jika fungsi produksi frontier diketahui, maka dapat diestimasi inefisiensi teknis melalui perbandingan posisi aktual relatif terhadap frontiernya.

Efisiensi usahatani juga sangat dipengaruhi oleh kemampuan manajerial petani. Petani yang masih subsisten dengan luas lahan yang sempit, biasa dikenal juga dengan istilah petani gurem 
(peasant), biasanya hanya memproduksi untuk dikonsumsi sendiri. Sisa yang dibawa ke pasar hanya sedikit, dan hanya memberi sedikit pendapatan. Ia asing dengan pasar, terbatas teknologinya, dan memiliki keterbatasan finansial dan kemampuan manajemen. Karena pertanian tidak cukup menghasilkan pendapatan, maka mereka harus mencari usaha lain untuk memenuhi pendapatannya. Soekartawi (2002) mengemukakan bahwa prinsip optimalisasi penggunaan faktor produksi pada prinsipnya bagaimana mengunakan faktor produksi tersebut seefisien mungkin. Dalam terminologi ilmu ekonomi, maka pengertian efisien ini dapat digolongkan menjadi 3 macam, yaitu:

a. Efisiensi teknis. Suatu pengunaan faktor produksi dikatakan efisien secara teknis kalau faktor produksi yang dipakai menghasilkan produksi maksimum. Efisiensi teknis akan tercapai pada saat elastisitas produksi (EP) berada diantara nol dan satu $(0<$ Ep $<1)$. Bila Ep $>1$; maka produksi total (TP) menaik pada tahap increasing rate dan produksi rata-rata (PR) juga naik. Hal ini terjadi pada tahap 1, di sini penambahan input faktor produksi akan meningkatkan produksi total maupun produksi ratarata. Karena itu, hasil yang diperoleh dari penambahan input faktor masih jauh lebih besar dari tambahan biaya yang harus dibayarkan. Daerah ini merupakan daerah produksi yang belum efisien atau pengunaan faktorfaktor produksi belum optimum. Bila $\mathrm{Ep}<0$; penambahan input faktor justru menurunkan produksi total. Pada daerah ini pemakaian faktor produksi sudah tidak efisien lagi dan disebut daerah irasional. Keuntungan masih dapat ditingkatkan selama nilai kenaikan hasil masih lebih besar dari nilai tambahan faktor produksi yang dipergunakan.

b. Efisiensi alokatif (efisiensi harga). Dikatakan efisiensi harga atau efisiensi alokatif kalau nilai dari produk marjinal sama dengan harga faktor produksi yang bersangkutan.

c. Efisiensi ekonomi. Dikatakan efisiensi ekonomi kalau usaha pertanian tersebut mencapai efisiensi teknis dan sekaligus juga mencapai efisiensi harga.

Hasil analisis pada Tabel 2 memperlihatkan bahwa effisiensi teknis pada usahatani lahan darat rata-rata sebesar 99,97\%, berarti bahwa penggunaan faktor produksi sudah 
mendekati efisien secara teknis. Efisiensi alokatif dan efisiensi ekonomis dihitung dengan menggunakan dual cost frontier secara analisis diturunkan dari Fungsi Stochastic Frontier.

Tabel 2. Distribusi Efisiensi Teknis, Efisiensi Alokatif, dan Efisiensi Ekonomis di Lahan Darat

\begin{tabular}{|c|c|c|c|c|c|c|}
\hline \multirow{2}{*}{$\begin{array}{c}\text { Tingkat } \\
\text { Efisiensi }(\%)\end{array}$} & \multicolumn{2}{|c|}{ Efisiensi Teknis (TE) } & \multicolumn{2}{|c|}{ Efisiensi Alokatif (AE) } & \multicolumn{2}{|c|}{ Efisiensi Ekonomis (EE) } \\
\hline & $\mathrm{N}$ & $\%$ & $\mathrm{n}$ & $\%$ & $n$ & $\%$ \\
\hline$<=40$ & 0 & 0.00 & 0 & 0.00 & 0 & 0.00 \\
\hline $40,01-50$ & 0 & 0.00 & 0 & 0.00 & 0 & 0.00 \\
\hline $50,01-60$ & 0 & 0.00 & 0 & 0.00 & 0 & 0.00 \\
\hline $60,01-70$ & 0 & 0.00 & 14 & 18.67 & 14 & 18.67 \\
\hline $70,01-80$ & 0 & 0.00 & 50 & 66.67 & 50 & 66.67 \\
\hline $80,01-90$ & 0 & 0.00 & 11 & 14.67 & 11 & 14.67 \\
\hline $90,01-100$ & 75 & 100.00 & 0 & 0.00 & 0 & 0.00 \\
\hline Jumlah & 75 & 100 & 75 & 100 & 75 & 100 \\
\hline Maksimum (\%) & 99.97 & & 84.80 & & 84.80 & \\
\hline Minimum (\%) & 99.97 & & 62.68 & & 62.68 & \\
\hline Rata-rata $(\%)$ & 99.97 & & 75.72 & & 75.72 & \\
\hline
\end{tabular}

Tabel 3. Distribusi Efisiensi Teknis, Efisiensi Alokatif, dan Efisiensi Ekonomis di Lahan Sawah

\begin{tabular}{|c|c|c|c|c|c|c|}
\hline \multirow{2}{*}{$\begin{array}{c}\text { Tingkat Efisiensi } \\
(\%)\end{array}$} & \multicolumn{2}{|c|}{ Efisiensi Teknis (TE) } & \multicolumn{2}{|c|}{ Efisiensi Alokatif(AE) } & \multicolumn{2}{|c|}{ Efisiensi Ekonomis (EE) } \\
\hline & $\mathrm{n}$ & $\%$ & $\mathrm{n}$ & $\%$ & $\mathrm{n}$ & $\%$ \\
\hline$<=40$ & 48 & 92.31 & 50 & 96.15 & 50 & 96.15 \\
\hline $40,01-50$ & 4 & 7.69 & 2 & 3.85 & 2 & 3.85 \\
\hline $50,01-60$ & 0 & 0.00 & 0 & 0.00 & 0 & 0.00 \\
\hline $60,01-70$ & 0 & 0.00 & 0 & 0.00 & 0 & 0.00 \\
\hline $70,01-80$ & 0 & 0.00 & 0 & 0.00 & 0 & 0.00 \\
\hline $80,01-90$ & 0 & 0.00 & 0 & 0.00 & 0 & 0.00 \\
\hline $90,01-100$ & 0 & 0.00 & 0 & 0.00 & 0 & 0.00 \\
\hline Jumlah & 52 & 100 & 52 & 100 & 52 & 100 \\
\hline Maksimum (\%) & \multicolumn{2}{|c|}{44,47} & \multicolumn{2}{|c|}{42.57} & \multicolumn{2}{|c|}{42.57} \\
\hline Minimum (\%) & \multicolumn{2}{|c|}{4,73} & \multicolumn{2}{|c|}{2.55} & \multicolumn{2}{|c|}{2.55} \\
\hline Rata-rata (\%) & \multicolumn{2}{|c|}{21,35} & \multicolumn{2}{|c|}{19.42} & \multicolumn{2}{|c|}{19.42} \\
\hline
\end{tabular}

Tabel 3, menunjukan rata-rata efisiensi teknisnya mencapai $21,35 \%$. Jika diperbandingkan, maka efisiensi teknis tertinggi dicapai oleh petani lahan darat, daripada petani lahan sawah. Dengan kata lain, petani lahan darat dapat mencapai efisiensi teknis yang tinggi. Rata-rata efisiensi alokatif dan efisiensi ekonomis pada petani lahan darat dan lahan sawah adalah 75,72\% dan 19,42\%. Hal ini menunjukkan bahwa masih terdapat peluang untuk meningkatkan efisiensi alokatif dengan mengurangi biaya-biaya yang sebetulnya tidak diperlukan. Petani lahan darat kisaran efisiensi alokatif antara 29-99\%, sedangkan petani lahan sawah berkisar $<$ $20 \%$. Jika dikomparatifkan, maka 
efisiensi alokatif pada petani lahan darat lebih baik dibanding petani lahan sawah. Efisiensi ekonomis merupakan gabungan dari efisiensi teknis dengan efisiensi alokatif. Pada petani lahan darat diperoleh rata-rata $\mathrm{EE}: 75,72 \%$, dengan kisaran 29,04-99,61\%. Hal ini berarti bahwa, jika petani lahan darat mampu mencapai tingkat efisiensi ekonomi maksimum, maka bisa menghemat biaya produksi sebesar $=1-75,72 / 84,80=$ 10,71\%. Tingkat efisiensi secara alokatif dan ekonomis dapat tercapai dengan adanya minimisasi biaya produksi. Minimisasi biaya dipengaruhi oleh faktor lain di luar produksi, yaitu dipengaruhi oleh harga dari input produksi dan harga output yang berlaku pada lokasi tersebut

\section{KESIMPULAN}

1. Terdapat satu variabel yang berpengaruh secara signifikan di lahan darat terhadap tingkat produksi kedelai yakni pupuk, sedangkan variabel luas lahan, benih, pestisida dan tenaga kerja, sedangkan petani di lahan sawah terdapat dua variabel yang berpengaruh secara signifikan terhadap tingkat produksi kedelai yakni luas lahan dan tenaga kerja, benih, pupuk, dan pestisida tidak signifikan. Petani kedelai baik di lahan darat maupun lahan sawah berada pada tahap III (Tahap Irasional).

2. Rata-rata nilai efisiensi teknis, efisiensi alokatif, dan efisiensi ekonomis di lahan sawah adalah 99,97; 62,68; dan 62,68; sedangkan di lahan sawah adalah 21,$35 ; 19,42$ dan 19,42. Nilai tersebut menunjukan bahwa usahatani kedelai di lahan darat lebih efisien jika dilihat dari nilai efisiensi teknis, efisiensi alokatif, dan efisiensi ekonomis.

\section{DAFTAR PUSTAKA}

Amaza, PS (2008). Penyelidikan faktorfaktor yang mempengaruhi efisiensi teknis produksi kedelai di sabana Guinea di Nigeria.

Badan Pusat Statistik. 2017. Statistik Indonesia 2017. Katalog: 1101001. https://www.bps.go.id/website/pdf publikasi/Statistik-Indonesia2017.pdf. Diakses pada Agustus 2019.

Coelli, T. (1998). Metodologi multi-tahap untuk solusi model DEA yang berorientasi. Surat Riset Operasi, 23 (3-5), 143-149.

Irawan, K., \& GUNANTO, E. Y. A. (2014). Analisis Efisiensi Produksi Kedelai di Kecamatan Pulokulon Kabupaten Grobogan Jawa Tengah (Doctoral dissertation, Fakultas Ekonomika dan Bisnis).

Isyanto, A.Y., Sudradjat, S., and Yusuf, M.N. (2021). Determinants of Technical In-efficiencies in Swamp Rice Farming - Ciamis District, Indonesia. E3S Web of Conferences 226, 00005 (2021). 
https://doi.org/10.1051/e3sconf/202 122600005

Koswara, S. (2009). Teknologi Pengolahan Kedelai (Teori dan Praktek). EbookPangan. com.

Las, I., Soedjana, T. D., Soeparno, H., Heriawan, R., Suryana, A., Jamal, E. \& Mulyandari, R. S. H. (2018). Sinergi Sistem Penelitian dan Inovasi Pertanian Berkelanjutan.

Liu, Xue., \& Brian J. Revell. (2009). Competitiveness changes in China's quality vegetable exports post-WTO. Journal of Chinese Economic and Foreign Trade Studies, Volume: 2 Issue: 2.

Mubyarto. 1989. Pengantar Ekonomi Pertanian. Jakarta: LP3ES.

Mulyani, A., Ritung, S., \& Las, I. (2016). Potensi dan ketersediaan sumberdaya lahan untuk mendukung ketahanan pangan. Jurnal Penelitian dan Pengembangan Pertanian, 30(2), 73-80.

Ningsih, S. (2014). Realistic Mathematics Education: Model Alternatif Pembelajaran Matematika Sekolah. Jurnal Pendidikan Matematika, 1(2), 73-94.
Pusat Data dan Sistem Informasi Pertanian. 2017. Perkembangan Produksi, Konsumsi dan Impor Kedelai di Indonesia, 2012-2016. Jakarta.

Rahayu, W., \& Riptanti, E. W. (2010). Analisis efisiensi ekonomi penggunaan faktor-faktor produksi pada usahatani kedelai di Kabupaten Sukoharjo. Caraka Tani: Journal of Sustainable Agriculture, 25(1), 119-125.

Simon Matakena. 2012. Efisiensi Penggunaan Faktor-Faktor Produksi Guna Meningkatkan Produksi Usahatani Kedelai di Distrik Makimi Kabupaten Nabire. Jurnal Agrilan Volume 1 No. 1 Oktober 2012

Soekartawi. 2002. Prinsip Dasar Ekonomi Pertanian Teori dan Aplikasi. Jakarta. PT. RajaGrafindo. 